\title{
STUDENTS' PERSPECTIVE ON USING TRANSTOOL IN CONVERTING ENGLISH TEXT TO INDONESIAN
}

\author{
Yovita Angelina, Magpika Handayani \\ Polytechnique of Tonggak Equator Pontianak \\ Yovita.angelina89@gmail.com, Magpikahandayani@yahoo.com
}

Submitted: 2020-02-08

Accepted: 2020-04-20

\begin{abstract}
This study aims at analyzing the usage of Transtool by students in converting of English text at Sekolah Tinggi Bahasa Asing. The analysis is based on Transtools that commonly used by students to help in learning. Sekolah Tinggi Bahasa Asing is one of the colleges in Pontianak and one of the subjects that is taught is translation. This research is descriptive qualitative research in which the writer took 15 students of Sekolah Tinggi Bahasa Asing as a participant to ask their perspective about the usage of Transtool in converting English to Indonesian. These 15 students having a high score in translation subject and frequently using Transtool for converting English text into Indonesian in class. The result of interview shows that the use of transtool in converting text help them understand instruction that is given by the lecturer. Transtool helps students to understand the instruction easily and make their work quicker compared to manual process. The feature of transtool is easy to use that make this application is easily operated;moreover, The students are not only helped to convert for their field of study, but the application also can be used to help students converting other field of study that is not learnt by them.
\end{abstract}

Keywords: Students' Perspective; Translation Tool; Converting English text; Sekolah Tinggi Bahasa Asing

\section{INTRODUCTION}

English is used as a means of communication for a global community. As a global language, English has an important role in international interaction. In Indonesia, the Government added English Language in their curriculum of education for elementary school, middle school and high school that is expected to help students to be able to communicate fluently as their second language. The function of English is used widely in international interactions include relationship between countries, business, tourism, and others. In this kind of international interaction, English primarily acts as the lingua franca which is useful to be applied in conference that each nation presents a representative and they communicate in English. English is a language that is used to communicate among different people from different countries (Sneddon, 2003).

In Indonesia, English is a foreign language. By learning English, people gain more knowledge about language and we have much better chance of understanding. There are skills to learn English language, like reading, writing, speaking and listening and they are the four foundational skills of language learning. Converting text might be an important thing in written communication. Converting might involves some language components (spelling, grammar, vocabulary, and punctuation). Those components are important in helping students converting English into Indonesian. Communication is the reasons why there are many people want to have 
ability in converting the text. To communicate well, people must have capabilities in understanding text and find its equivalent in the target language. Therefore, they need to know the steps in communication and grammatical aspect. People who want to have skill in converting English text must be able to organize the idea, construct the sentences, understand the culture of foreign language, and speak well.

Generally, people use a Transtool in finding the gist of the message from their first language to other language as a target by translating phrase or sentence in source language to target language. It might indicate that technology has developed so fast especially in Translation Applications that commonly used by people to help their social activities and learning. People use application to get information, to chat and communicate with family or friends, to learn, to help in selling products, and etc. In addition, the role of technology can be used as a learning tool to develop people ideas. The development of the technology tempt people operating one of the relevance tool or media to help them in learning especially in English. There are many methods which can help the students to improve their English proficiency; one of them is by using Transtool. This idea is based on the writer experience in observing students in the class using the tool to help them in finding the words or phrase to support their writing or speaking. Transtool may help and encourages people to learn and improve their interest. Transtool may make a lot of fun by searching and exploring word by word. Whenever the student search for the meaning of the word or sentences to find the unfamiliar words, they can improve their knowledge, and they should see the unfamiliar words and analyze it.

Sekolah Tinggi Bahasa Asing is one of the colleges in Pontianak, and translation is one of the subjects that is taught. In translation subject, students usually find difficulties to express something that might be caused by many factors. One of the factors is the difficulties in converting the language from Bahasa Indonesia into English or English into Bahasa Indonesia. Students in this situation need something to help them in pouring their idea from Bahasa into English. One of the applications that are used by students at Sekolah Tinggi Bahasa Asing in translation is Transtool. The writer would like to know whether the use of Transtool is helpful for the students in converting words or phrase into Indonesian. Moreover, the writer would like to explore if the application can be used for them in converting specific field of study.

\section{LITERATURE REVIEW}

Translation process may help human to know other language meaning due to various of languages in the world. The process of translating the text has affected many people in maintaining their communication with one another, (Fenton, 2014, p.38). One of the media that is used by people in order to ease the process is Translation tool. According to Goutte, Cancedda, Dymetman, \& Foster (2009, p. 131), Transtool is a machine translation that is 
developed by combining syntactic information into machine translation system. Transtool might be used by people who want to understand about the meaning of words and sentences from a language to another languages and one of them is Indonesian to English or from English to Indonesian. It might be able to translate words, sentences and web pages between any combinations of the supported languages that is adjusted with the target language or in other words, the language has been control in order to find fix term, (Cardey, Greenfield, and Wu ( Cited in Frederking \& Taylor (2005, p.38). Followed by, Maulinda (2017) in specific wrote that Google Translate is known as media social networking which almost every people used it to translate or to understand about the meaning of the words and sentences by online. Furthermore, Ismail (2016) wrote that Google Translate can also be used to minimize the student's translation tasks because the translation results are promptly produced. The translator is also assisted with the easiness and availability of the machine which are online and accessible to anyone. According to Robinson (2012, p.16), "the most important thing is that of the translations be done reliably and quickly. However, it is important to know that the mot important thing in understanding meaning between words and things is identifying the words in different language that is adjusted with the context where the language is used, Benjamin (2014, p. 157).

\section{The Feature of Translation in Trantools}

The rapid development of technology has contributed for the translation activities, considering most of the books still in foreign languages. Therefore, there are many translators competing to make a new breakthrough in translation and the translator should be aware the fact that there are various type of translation and the uses.

There must be a different types in translating a text. According to Jakobson in Hatim and Munday (2004, p.5), there is difference between three types of written translation: The first is intralingual: the same language, which may involve rewording or paraphrase. The second is interlingual: cross language translation. The third is intersemiotic: translation of the verbal sign to non-verbal sign like music. In translation tool there are 5 features that help people in translating (Educatorstechology, 2016), they are as follows:

1. Pronouncing the words that is translated

Learning about the pronunciation of new term is similar to learning about its meaning. Translation tool provides the ability to listen to how the translated word is spoke in the language by simply clicking on the 'Listen icon' that shows up next to the translation.

2. Translating text in images

This element works on Translation tool Application for mobile devices. It allows translator to translate text included in photos and images.

3. Translating by speech 
People can address words or phrases and have them translated in the language that people want to.

4. Translating by handwriting

This element allows translator to handwrite words and phrases and have them promptly translated.

5. Translating documents

Transtool lets translator translate the entire documents with a single click that will allow people to translate it in easy way. This type tends to translate a document based on the sentence. Finding the meaning of sentence should be related to our logical inferences, (Aitchison, 2003, p. 98). The ability of Transtool translating the sentence might help students in getting the meaning correctly.

\section{The Function of Translation}

Translation has different means for different groups of people. Robinson in Pym (2012, p.6) said "from the perspective of external knowledge of non-translators, translation is a text; from the perspective of "internal knowledge" (translators) translation is an action that aims at the producing of text". This means that translation is needed to do the specific translations. Translation has a role as a function in interlingual communication activity around the world to gain information and the development of technology. Reiss in Venutti (2000, p.160) said "Interlingual translation is a two mediated process of exchange of ideas, which usually aims at the production of a target language text that is functionally equivalent to source language text". One clear statement is expressed by Levy in Venutti (2000, p. 148) that "Translation is a process of ideas idea exchange through written or spoken language: the purpose is to communicate the knowledge of the original to the other reader who speak different language.

\section{The Use of ICT in Learning}

Modern ICT tools are taken on by thousands of institutions because they are convenient and unrestricted, captivating and exciting to adopt, which makes them necessarily important to be incorporated into education and most specially to enhance and enable social gatherings. Furthermore, information and communication technologies (ICTs) are main factors in shaping economy in largescale that bring about fast producing changes in society. The rise of the 'knowledge-based' society is changing the education and economy globally. ICTs may help in expanding approach to education, strengthen the significance of education to digital work place, and raise educational quality by assisting to make teaching and learning an engaging, active process connected to real situation. ICTs have been considered as the blend of technologies for gathering, keeping, processing, communicating and delivering information. According to Wilks 
(2009, p.1) the use of ICT like machine translation is beneficial for people around the world because it is able to give fully automatic translation.

The writer would like to study the previous finding through the use of google translate in understanding the lecturer instruction. Based on the research conducted by Maulinda (2017), Google translate in the form of an application is certainly much easier than having to carry a dictionary then the student feel helped by the existence of the application (Google Translate) to understand the lecture material that speaks English and they must translate it first then understand it. Moreover, the result of related study in empirical study, Maulinda (2017), and Adam Ismail (2016). The data findings also showed that statistical method of Google Translate, the inability of Google Translate to understand the contexts of the texts beyond sentence, and errors in the source texts that carried into translation errors in the target texts were the causes of translation errors found in the data. Based on the previous study, the writer would like to know the student's perception related to the usage of Transtool in helping students translate from English into Indonesia specially to know the accuracy.

\section{METHOD}

\section{Research Preparation}

This research is descriptive qualitative research. According to Lodico, Spaulding and Voegtle (2010, p.112), "descriptive research describes performances and to collect respondents' perceptions, opinions, attitudes, and beliefs about a current issue in education". Lodico, Spaulding and Voegtle (2010, p.26) also said that "Ultimately the researcher is the primary measurement tool in qualitative research; all data are filtered through the researcher's eyes and ears. Therefore, qualitative measures usually include tools to record the subjective experiences of the researcher for analysis". Furthermore, the writer is going to use in-depth individual interviews with the students to analyze the usage of Translation tool Application in converting English text into Bahasa Indonesia at Sekolah Tinggi Bahasa Asing Pontianak. The writer did pre research by discussing the planning with the student in STBA Pontianak to ask them about the use of Transtool in the class before conducting the research. The writer afterward decides to ask the students perception about the usage of Translation tool in helping them converting the text from English into Indonesia.

\section{Informants}

According to Scott and Usher (2011, p. 90), "qualitative research a sample of all cases that constitute a population is identified". Therefore, the writer took Sekolah Tinggi Bahasa Asing as the social situation in this research. Then, the sample of this research would be the sixth semester that already took the translation course in their latest semester that the second and fourth semester have not and for the sixth semester students there are 30 people and only 1 class. Then the writer took 15 students of Sekolah Tinggi Bahasa Asing as a participant which 
are these 15 students meet a criteria such as having a high score in translation 1 and active in using Transtool in writing and speaking class afterward they represent other students as informant. The reason that 15 students are selected because the writer would like to get the data from students who have special knowledge or have good translation subject score, (Borg \& Gall, 2007, p 243). Moreover, the writer use purposive sampling to get the actual and accurate data in this research. According to Patton in Lodico, Spaulding and Voegtle (2010, p.134), "The logic and power of determined sampling is in selecting information Information are those from which someone can learn many problems of central importance to the purpose of the research". Therefore, the participant were the student who ever translated text in the class and willing to be interviewed.

\section{Data Collecting Tools}

Data that is obtained in qualitative research might be from various way. "Qualitative researchers normally include more than one data collection technique or use the same technique at different times to validate findings", (Lodico, Spaulding and Voegtle, 2010, p.204). Researchers need to hold in using the interview method:

a) The subject (respondent) is the person who knows about himself.

b) What is stated by the subject to the researcher is true and reliable.

c) The interpretation of the subject about the question asked by the researcher to him is the same as what was intended by the researcher

1. Interview

According to Lodico, Spaulding and Voegtle (2010, p.122), “As In interviews, as in surveys, persons are presented with questions to answer. However, questions on surveys typically require only brief responses. Interviews can provide much more depth and explore more complex beliefs, knowledge, or experiences than can a survey". From the explanation above, Interview is a review tool or proof of information or evidence in research. Therefore, the writer will use recorder and take notes to collect the data in this research. Therefore, interviews were conducted to get accurate information and actual data from the student of Sekolah Tinggi Bahasa Asing and it was according to the main problem or condition that the writer need. In the interview session there were 7 questions related to the student's perspective of the usage of Translation tool in converting English text to Indonesia. The interview was conducted to 15 students of STBA Pontianak, and each student was interviewed for 20 minutes related to their perspective about the use of Translation tool in converting text from English to Indonesian.

\section{Technique of Data Analysis}

The data analysis was data reduction, data display, and conclusion or drawing/verification. According to Lodico, Spaulding and Voegtle (2010, p.165), "The 
researcher concludes and explains the results by explaining the major ideas, patterns, or themes that arise from the analysis". After getting the data, the writer collected the students answer one by one and interpreted the result. After finish doing the analysis, the writer matched the answer from questionnaire with the answer of students' interview.

\section{Data Reduction}

Lodico, Spaulding and Voegtle (2010, p.180), state that Data reduction is simplified, telling main things, focusing on important things, looking for themes and the patterns through induction process. That statement implies that data reduction is defined as selecting the core, focusing on important things, looking for the theme and pattern and deleting the unnecessary. Therefore, from the result of the interview, the unnecessary data was deleted and the writer gathered the data that was necessary from the interview result.

\section{Data Display}

In this research, the data was presented briefly by the writer. By showing data, it is easier to understand what is happening, and the writer can plan further work based on what has been understood." Displaying data helped the writer to understand what is happening, the caution on that understanding and further analysis that is needed to be done. Therefore, the writer transcripted the result from the interview session with the students of Sekolah Tinggi Bahasa Asing Pontianak.

\section{Conclusion Drawing/Verification}

The last is analyzing qualitative data. According to Lodico, Spaulding and Voegtle (2010, p.192). "The conclusion in qualitative research is a finding which is found through the participants own words and represented by the researcher. Findings is a description of an object which was dim or not clear after being researched, it might be a casual or collaborative relationship theory." That statement above implies that when the initial conclusion is supported by valid and consistent proofs when writer collects the data in the field, the conclusion stated is credible conclusion.

\section{FINDING AND DISCUSSION}

\section{The usage of transtool in converting English text into Indonesian}

There were 15 from 30 students that is interviewed in this research. The writer chose the sample based on their frequency in using Transtool. Most of students that is interview have been using transtool more than a year. They have been using Transtool since the first year in STBA. The reason of using Transtool is because there are many instruction and material they need to understand. Based on the information that is obtained from the informant about the usage of Transtool in converting English text into Bahasa Indonesia, 14 students or most of the students 
think that Transtool is a useful application that can be used to convert English text into Bahasa Indonesia. The informant said that the use of transtool in converting text from book and help them understand instruction that is given by the lecturer. Transtool helps students to understand the instruction easily and make their work quicker compared to manual process. The feature of Transtool is easy to use that make this application is easily operated. One students think that the usage of Transtool is good but there is another application that is used by him that is considered similar and even easier for him to use. Moreover, the use of Transtool application for students is a good application in converting specific field of study. The students are not only helped to convert for their field of study, but the application also can be used to help students converting other field of study that is not learnt by them.

\section{Transtool usefulness in converting English text into Indonesian}

The writer investigate the usefulness of Transtool in converting English Text into Indonesia. From 15 informants that was interviewed, most of them said that Transtool is useful in making the work simple and helpfull to understand instruction; moreover students think that transtool application help them to understand grammar and sentence formation process. They found that in the process of converting English text into Indonesia, the sentence and phrase is logic and easily understood by them. The sentence and phrase that is translated in Bahasa Indonesia is accepted based on the characteristic of Bahasa Indonesia as a target language. The following is the table of students' perspective in using Transtool in converting English into Bahasa Indonesia

Interview result on students' perception on using translation tools in converting English text into Indonesia

\begin{tabular}{|c|c|c|c|}
\hline Aspect & Classification & Frequency & Informant \\
\hline \multirow{2}{*}{$\begin{array}{l}\text { The usage of Transtool is } \\
\text { efficient }\end{array}$} & Yes & 14 & \multirow[t]{2}{*}{15} \\
\hline & No & 1 & \\
\hline \multirow{2}{*}{ Their interest in using Transtool } & Yes & 14 & \multirow[t]{2}{*}{15} \\
\hline & No & 1 & \\
\hline \multirow{2}{*}{$\begin{array}{l}\text { Transtool is helping in making } \\
\text { text easy }\end{array}$} & Yes & 15 & \multirow[t]{2}{*}{15} \\
\hline & No & 0 & \\
\hline \multirow{2}{*}{$\begin{array}{l}\text { Transtools is helpful in } \\
\text { communication }\end{array}$} & Yes & 15 & \multirow[t]{2}{*}{15} \\
\hline & No & 0 & \\
\hline \multirow{2}{*}{$\begin{array}{l}\text { The easiness in operating the } \\
\text { application }\end{array}$} & Yes & 15 & \multirow[t]{2}{*}{15} \\
\hline & No & 0 & \\
\hline \multirow{2}{*}{$\begin{array}{l}\text { The result of translating text } \\
\text { using Transtool is accurate }\end{array}$} & Yes & 14 & \multirow[t]{2}{*}{15} \\
\hline & No & 1 & \\
\hline \multirow{2}{*}{$\begin{array}{l}\text { Transtool in converting English } \\
\text { text into Indonesia is useful }\end{array}$} & Yes & 15 & \multirow[t]{2}{*}{15} \\
\hline & No & 0 & \\
\hline
\end{tabular}




\section{CONCLUSION}

Based on the interview with informant, and data reduction process, the writer would like to draw the conclusion related to students perception on Using Transtool in Converting English Text into Indonesian. The result show that transtool is helpful in converting text from book, and help them understand the instruction that is given by the lecturer. Transtool helps students to understand the instruction easily and make their work quicker than ordinary process. The feature of Transtool is easy to use that make this application is easily operated. One students think that the usage of Transtool is good, effective, and even easier to use. Moreover, students found that in the process of converting English text into Indonesia, the sentence and phrase is logic and easily understood. The sentence and phrase that is translated into Bahasa Indonesia is accepted based on the characteristic of Bahasa Indonesia as a target language.

\section{REFERENCES}

Aitchison, Jean.2003. Teach yourself Linguistics. Sixth Edition. USA. McGraw-Hill

Benjamin, Andrew. (2014). Translation and the Nature of Philosophy. A New Theory of Words. New York. Routledge.

Borg, Walter R, Gall, Joyce P \& Gall, Meredith D. (2007). Educational Research. Eight Edition. USA. Pearson

Fenton, Sabine. (2014). For Better or Worse: Translation as a tool for change in the south Pacific. London and New York. Routledge.

Frederking, Robert E \& Taylor, Kathryn B. (2005). Machine Translation: From Real Users to Research. Washington DC. USA. Springer

Goutte, Cyril, Cancedda, Dymetman, Marc, and Foster, George. (2009). Learning Machine Translation. London. MIT Press.

Hatim, B., \& Munday, J. (2004). Translation: An advanced reference book. London and New York: Routledge.

Harmer, J. (2001). The practice of English language teaching ( $3^{\text {rd }}$ ed.). London: Longman.

Ismail, A. (2016). Errors Made In Google Translate In The Indonesian To English Translations of News Item Texts. Journal of English Language Teaching 5 (2).http://journal.unnes.ac.id/sju/index.php/elt

Lodico, M. G., Spaulding, D. T., \& Voegtle, K. H. (2010). Methods in educational research : From theory of practice. (2nd ed.). San Fransisco: Jossey-Bass

Maulinda, H. (2017). Persepsi mahasiswa terhadap penggunaan google translate sebagai media menerjemahkan materi berbahasa inggris.Jurnal Saintekom, Vol.7, No.1. 
Robinson, D. (2012).Becoming a translator: An introduction to the theory and practice of translation, $\left(3^{\text {rd }} e d\right.$.). London and New York: Routledge.

Scott, David \& Usher, Robin. (2011). Researching Education. Data methods and Theory in Educational Enquiry. 2th Edition. New York. Continuum.

Sneddon,J.(2003). The Indonesian language : Its history and role in modern society. Sydney: UNSW Press.

Venuti, L. (2000). The translation studies reader. London: Routledge.

Wilks, Yoricks. (2009). Machine Translation. Its Scope and Limits. UK. Springer 